LETTERS

\section{The "piriformis syndrome"- myth or reality?}

In the above editorial, ${ }^{1}$ I noted the desire to package these rather indeterminate pains in the buttock, around the trochanter, and which can radiate to the groin or knee, as a deep gluteal syndrome. The pririformis syndrome and the hamstring syndrome ${ }^{2}$ do I believe exist, but in my admittedly very small experience, as they are rare, they do have a major clinical finding that differs from pain induced by the hip stabilisers. Because the sciatic nerve is involved, the straight leg raise, Laseque and Bowstring signs, which produce neural stress peripheral to the lesion, are positive, but the slump test, which moves the dura and is proximal to the lesion, is negative. Most patients diagnosed as having "piriformis syndrome" do not have these clinical findings, and their problem better fits the classification of deep gluteal syndrome. Perhaps, in fact, the deep gluteal syndrome diagnosis should be used as well as, and not inclusive of, the piriformis and hamstring syndromes. I feel the gluteals are often not involved and perhaps an even broader term such as hip stabiliser syndrome should be considered.

M T F Read 7 Waterden Road, Guildford, Surrey GU24 OLX, UK

\section{REFERENCES}

1 McCrory $\mathbf{P}$. The piriformis syndrome-myth or reality. Br J Sports Med 2001;35:209-10.

2 Puranen J, Orava S. The hamstring syndrome. A new diagnosis of gluteal sciatic pain. Am J Sports Med 1988;16:517-21.

\section{BOOK REVIEWS}

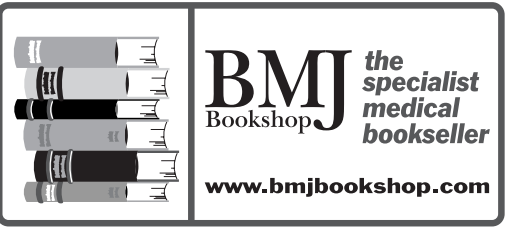

\section{Sports injuries: their prevention and treatment, 3 rd edn.}

L Petersen, P Renström. London: Martin Dunitz, $£ 29.95$ (price with CD ROM £49.95), pp 554; ISBN 1-85317-119-0.

To review this book is no easy task. It is a bit like being asked to do a book review of The Bible. It seems like this reference book has been on our shelves since Moses played half back for Egypt, and few sports physicians world wide will not have read it at some stage of their career. Many of us have used the extensive pictures from earlier editions of the book to illustrate our lectures. The authors and publishers are to be commended that one can also now purchase these illustrations on a separate CD ROM. Bowing to the inevitable consumer

\section{Rapid responses}

If you have a burning desire to respond to a paper published in $\mathrm{Br} J$ Sports Med, why not make use of our "rapid response" option?

Log on to our website, find the paper that interests you, click on "full text" and send your response by email by clicking on "eletters submit a response".

Providing it isn't libellous or obscene, it will be posted within seven days. You can retrieve it by clicking on "read eletters" on our homepage.

The editors will decide, as before, whether

to also publish it in a future paper issue. www.bjsportmed.com

demands, nevertheless this makes an important "value added" aspect to the book.

The fact that this book is now in a 3rd edition says something important about the development of sports medicine. We have reached the stage where important textbooks such as this one have been developing over almost 30 years, paralleling the growth and increasing sophistication of the discipline of sports medicine.

Like The Bible, Sports injuries is a multiauthored book, strong on orthopaedic trauma and weak on return to play issues. As one would expect from a text authored by two internationally renowned surgeons, the orthopaedic aspects of injuries are particularly strong. New sections in this 3rd edition enhance the book significantly. This is particularly impressive in the shoulder trauma section, where I see that Ben Kibler's slide test is elevated to sainthood. As I revisited this book for the purpose of this review, I am struck just how much orthopaedic sports medicine has changed since I began in this area. Concepts such as SLAP lesions, autologous chondrocyte transplantation, and labral tears were not even described when I did my first sports medicine course, yet in this book, accompanied by beautiful illustrations, such concepts are made crystal clear. All budding sports clinicians, regardless of discipline, should read this textbook as a starting point for their careers in sports medicine.

This book is meant to be about sports injuries, and, not surprisingly, its weakest aspect is the medical coverage of sporting problems. There is virtually nothing on cardiorespiratory or neurological problems or physiological adaptations in sport. As I mentioned, the book is designed to cover sports injuries, and it would need a multivolume text to do justice to every aspect of sports medicine. One area that overlaps sports medicine and sports trauma, however, is the issue of head injury and concussion. It is here that this book is particularly lacking. This section is both outdated in approach and incorrect in its terminology and provides no useful guidance on return to play. Perhaps in the 4th edition this will be rectified! Despite this quibble, Sports injuries justifiably deserves its place in the pantheon of sports medicine textbooks.

The overview of general concepts makes this work the best single reference for new sports medicine trainees and those involved in athletic care. Similarly the sections on rehabilitation and training are very useful and many of the suggested exercises can easily be adapted for patient handouts or information.

Reviewing this book is a bit like meeting an old and dear friend that one hasn't seen for some time. The easy familiarity is still there, the style of the illustrations remains distinctive, and yet the book is far more evolved and sophisticated. What was an excellent book in its earlier existence is now even more impressive in its scope and coverage of sports medicine. This book gets my vote for sports medicine book of the year. A "gold medal" performance!

\section{Analysis}

\section{Presentation}

Comprehensiveness

$18 / 20$

Readability

$20 / 20$

Relevance

$20 / 20$

Evidence basis

$5 / 20$

Total

$81 / 100$

P McCrory

Centre for Sports Medicine Research and Education, School of Physiotherapy, Level 1, 200 Berkeley Street, Parkville, Victoria 3052, Australia; pmccrory@compuserve.com

\section{Physical activity and bone health.}

Edited by K Khan, H McKay, P Kannus, D Bailey, J Wark, K Bennell. Champaign, IL: Human Kinetics, 2001, £38.50, pp275, HB. ISBN 0-88011-9683

Karim Khan (co-author of Clinical Sports Medicine) has gathered together an international group of experts to present Physical activity and bone health.

The preface describes many professionals who may be interested in this text-from personal trainers through to professors. Essentially everyone!

The book is divided into five sections, and is well set out and easy to read. It has excellent summaries at the end of each chapter allowing the reader to skim through to find appropriate chapters.

The first section on "Structure, function, and measurement of bone" provides detailed descriptions of the anatomy, physiology, and biomechanics of bone. There is a useful chapter on the techniques used to measure bone density and bone metabolism, which provides insigh into the background information required to interpret these results in a clinical setting.

A well referenced guide to dietary supplements and their role in fracture risk reduction in postmenopausal women is contained in Part Two.

There is a chapter devoted to men, a group often overlooked in the discussion of bone health. Other chapters in Part Three include exercise programmes for improving bone health in specific groups (children and premenopausal and postmenopausal women). These exercise guidelines are practical, include photos and diagrams, and could be given directly to patients during a consultation.

Part Four looks at "Intense physical activity and bone health". This section is most relevant to the athletic population. It gives an excellent overview of the literature but only general outlines on the management of menstrual disturbance, low bone mineral density, and stress fractures in athletes. 
Unusual features of this book are a section on "Research opportunities" for Masters and PhD students and an appendix summarising references from the text which the authors claim will be updated on a website as new literature is published-keep an eye on that one!

This book is an extensive and excellent reference of the literature in the area of bone health. As a clinician dealing with female athletes on a regular basis, it expanded my knowledge base but it may not be very useful for clinicians looking for a "how to" guide to clinical treatments in this complex area.

Analysis

Comprehensiveness

Relevance $13 / 20$

Evidence basis $\quad 18 / 20$

Total 83/100

S White

Sports Physician, Olympic Park Sports Medicine Centre, Swan Street, Melbourne 3004, Australia susanwhite@optusnet.com.au

Motivational styles in everyday life: a guide to reversal theory.

Edited by M J Apter. Washington: American Psychological Association, 2001, £33.95, pp 373; ISBN 1-55798-739-4.

I feel that this book is targeted towards academics, researchers, and people interested in motivation psychology generally, particularly reversal theory. As outlined in the preface and introductory chapter, reversa theory is a broad psychological theory which has received little attention from mainstream psychology. It specifically explores motivation, emotion, and personality.

The book is clearly a comprehensive overview of the research and application of reversal theory to date. To ensure this, the editor, Michael Apter, who is himself an expert in reversal theory and the most significant contributor to the work, appears to have drawn upon the expertise of the people most interested in the theory so far.

The content includes an introduction to the theory and field, with an outline of the empirical research that has so far been conducted. This is a detailed description of the theory, with the consequence that it is certainly not light reading; however, this attention to detail is required for the uniniti ated to grasp the terminology developed which describes the basics of the theory.

The sections entitled "Research applications" and "Practical applications" are probably of most relevance and interest to those not fully engrossed in the theory development. These sections include the application of reversal theory to a range of behaviours including smoking, sport, addiction, stress, organisations, and counselling. Although at times the theory provides a refreshing perspective on these areas, it tends to be somewhat too theoretical and limited in outlining how to use the theory in these areas.

Considering the relatively young age of reversal theory, which had its origins in the early 1970s, it is possible that applications will be developed further over time. Indeed, future issues are discussed at the conclusion of the book

In summary, this outline and review of reversal theory to date would be of most interest to psychology academics. The structure and outline of the book is good, but the terminology and theoretical emphasis make it slow going at times.
Analysis

Presentation

Comprehensiveness

Readability

Relevance

Evidence basis

Total

$13 / 20$

$18 / 20$

$13 / 20$

$12 / 20$

$12 / 20$

$68 / 100$

A Klarica

Psychologist, Olympic Park Sports Medicine Centre, Swan Street, Melbourne, Victoria 3000, Australia ajklarica@yahoo.com

\section{CALENDAR OF EVENTS}

First Asia Pacific American

College of Sports Medicine

(ACSM) Clinical Track Exercise

\section{Specialist Course}

25 February-1 March 2002, Singapore

Web site: www.lww.com/acsmcrc/clindts.html

The Sixth International Paralympic Committee Scientific Congress

4-6 March 2002, Salt Lake City, USA

Further details: Michele E Brown, PO Box 45002, Salt Lake City, Utah 84145-002, USA; email: michele.brown@saltlake2002.com

\section{OSCA ACPSM Conference}

10 March 2002, London

NSMI in partnership with ACPSM and OSCA Further details: Isabel Lancoma, NSMI; tel: +442074863974 ext. 219; email isabel.lancoma@nsmi.org.uk

Intermediate First Aid Course for Sports Doctors and Physiotherapists

20-24 March 2002, Queen's Medical Centre, Nottingham, UK

Further details: email: Kelly.Goodwin@ nsmi.org.uk

\section{International Football and Sports Medicine Conference}

22-24 March 2002, Beverly Hilton, Beverly Hills, California, USA

Web site: www.sportsmed.org

2002 Victorian Conference of

Science and Medicine in Sport and Exercise and 2002 SPA Sporting Knee Symposium

March 23-24 2002, Sidney Myer Asia Centre, University of Melbourne, Austrialia

Further details: Angela Cox, tel: 6139654 7733; fax 6139654 8556; email: members@ vic.sma.org.au

\section{Core Stability Essentials}

20-21 April 2002, UK

Further details: Isabel Lancoma, NSMI; tel: + 442074863974 ext. 219; email: isabel.lancoma@nsmi.org.uk

Drugs in Sport: The responsibilities of the health care professions

30 April 2002, The Commonwealth Institute, London, UK

Web site: http://web3.bma.org.uk/confweb.nsf
Fourth International Symposium on Safety in Ice Hockey

5-6 May 2002, Pittsburgh, PA, USA

Further details: Alan Ashare; email aashare@semc.org

$6^{\text {th }}$ World Conference on Injury Prevention and Control. Injuries, Suicide, and Violence: Building Knowledge, Policies, and Practices to Promote a Safer World

12-15 May 2002, Montreal Convention Center, Montreal, Canada

The purpose of the conference is to bring together the stakeholders to facilitate exchange between sectors and disciplines; promote the sharing of knowledge and intervention models and encourage partnerships between the public and private sectors.

The conference will include plenary sessions on topics of concern to all professions (for example, the influence of the media on the safety of populations: the role of policies and laws) and state of the art presentations focusing on their respective fields. Simultaneous translation of these sessions and the opening and closing ceremonies will be available in French and Spanish. Additionally, as the focus is to facilitate exchange, parallel sessions (oral presentations, round tables, and debates) and poster sessions will be organised around six major themes: Road Safety, Occupational Safety, Sport, Leisure, Home, Institutional and Product Safety, Suicide Prevention, Violence Prevention, and Post-trauma care and Rehabilitation.

Further details: Carol Pincox-Langevin; tel: +1 514848 1133; fax: + 1514288 6469; email: trauma@coplanor.qc.ca

Web site: www.trauma2002.com

\section{World Conference on Women and Sport}

16-19 May 2002, Montreal, Quebec, Canada

Further details: Deena Scoretz (secretariat), IWG Secretariat, 15 Eddy Street, $8^{\text {th }}$ Floor Hull, QC KlA OM5, Canada; tel: + 1604999 0989; fax: + l 819956 8019; email: dscoretz@infoserve.net

Web site: www.iwg-gti.org

\section{$49^{\text {th }}$ ACSM Annual Meeting}

20 May 2002 to 1 June 2002, St. Louis, Missouri, USA

Further details: Fax: + 1 (317) 6347817

\section{FIMS World Congress of Sports Medicine}

5-9 June 2002, Budapest Congress Centre, Budapest Hungary

Further details: Congress Secretariat Asszisztencia Kft, H-1132 Budapest, Visegradi u. 25; tel: +36 1350 1854/350 1892; fax: +36 1350 0929; email: assziszt@euroweb.hu Web site: www.asszisztencia.hu

\section{Physical Therapy 2002}

\section{5-8 June 2002, Cincinnati, Ohio, USA}

Further details: 2002 Annual Conference Program Committee, C/o Professional Development, APTA, 1111 North Fairfax St. Alexandria, VA 22314-1488 USA 
$9^{\text {th }}$ World Symposium of Biomechanics and Medicine in Swimming

21-23 June 2002, St. Etienne, France Further details: Jean-Claude Chatard, Pav 12, St JB, CHU de Saint Etienne, 42055 St Etienne Cedex 2, France; tel: +33477 1272

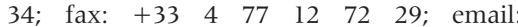
chatard@univ-st-etienne.fr

Website: www.univ-st-etienne.fr/swimsymp

\section{$12^{\text {th }}$ Commonwealth}

\section{International Sports Conference}

19-23 July 2002, Manchester, UK

Further details: Conference Secretariat, HIT Conferences, Cavern Court, 8 Mathew Street, Liverpool L2 6RE, UK; tel: +44 (0)151 227 4423; fax: +44 (0)15l 236 4829; email: sport@hit.org.uk

Website: www.hit.org.uk/sport/home.htm

\section{Fourth World Scientific Congress of Golf}

23-26 July 2002, St Andrews, UK

Further details: World Scientific Congress of Golf Trust, The Scores, St Andrews KY16 9AT UK; tel: +44 (0)1334 475560; fax: +44 (0)1334 474322; email: golfscience@ st-andrews.ac.uk Website: www.golfscience.org.

\section{Sports Medicine Course}

3-10 August 2002, Vancouver, Canada

Further details: Cathy Means; tel: + 1608263 6637; fax: +1 608262 8421; email: cjmeans@ facstaff.wisc.edu

\section{IEA World Congress of Epidemiology}

18-22 August 2002, Montreal, Canada Further details: Conference Secretariat, Events International Meeting Planners, 759 Square Victoria, Suite 300, Montreal, Quebec, H2Y 2J7, Canada; tel: +1 514286 0855; fax +1 514286 6066; email: info@eventsintl.com Website: www.iea2002.com

\section{Kinesiology-New Perspectives. $3^{\text {rd }}$ International Scientific Conference}

25-29 September 2002, Opatija, Croatia

Further details: Conference Office, Faculty of Kinesiology, 10,000 Zagreb, Horvacanski zavoj 15, Croatia; tel: +385 13658 666; fax: +358 1 3634 146; email: natalija.babic@ffk.hr

\section{The Queen's Golden Jubilee and Post Commonwealth Games BASEM Congress 2002}

10-13 October 2002, The Low Wood Hotel and Conference Centre, Indermere, Cumbria, UK

keynote lecturers

Professor Stuart M McGill (Canada), will lec ture on "Low back exercise: the foundation for building the best programme" and present a workshop on "a programme to enhance spine stability". Assistant Professor Karim Khan (Canada), will lecture on "Better management of tendinopathies" and "Physical activity and bone health". Other speakers include: Professor Dr med Hans H Paessler (Germany) lecturing on "Current concepts in knee ligament reconstruction following sports injuries" and "Rehabilitation after cruciate ligament reconstruction"; $\mathrm{Mr}$ Peter
Hamlyn (United Kingdom), Chairman of the Government Ministerial Working Group Report on Saftey and Medicine in Sport, will open and Chair a discussion on progress one year on from the report.

Further details: Mrs Sue Roberts, BASEM Company Office, 12 Greenside Ave, Frodsham, Cheshire WA6 7SA, UK; tel/fax: +44 (0) 1928 732 961; email: basemoffice@compuserve.com Website: www.basem.co.uk

\section{Sports Medicine of Australia 2002 Australian Conference}

12-16 October 2002, Carlton Crest Hotel, Melbourne, Australia

Further details: Prue Robertson, Project Officer, Sports Medicine Australia, PO Box 237, Dickson ACT 2602; tel: +02 62304650 fax: +02 6230 5908; email: prue.robertson@ sportnet.com.au

\section{Celebrating 50 years of Orthopaedics in Singapore}

13-16 October 2002, Singapore

In conjunction with the 25th Singapore Orthopaedic Association Meeting, 22nd Asean Orthopaedic Association Meeting, 5th Combined Meeting of Spinal and Paediatric Sections-APOA, 7th Meeting of Sports Medicine Section-APOA, 3rd Meeting of Asiapacific Orthopaedic Society for sports Medicine.

Further details: 2002 COM Secretariat, c/o Dept of Orthopaedic Surgery, National University Hospital, 5 Lower Kent Ridge Road, Singapore 119074, Republic of Singapore; tel: +65 772 4340; fax: +65 778 0720; email: secretariat@soa.org.sg

Website: http://orthopaedics2002.calendarone. com

\section{The 5th Asian Federation of Sports Medicine Congress}

24-27 October 2002, Seoul, South Korea

Further details: AFSMC 2002 Seoul Secretariat, Hanjim Travel Service Co Ltd, (c/o Young CHANG Marine Center New Bldg 5th Fl, \#51, Sogong-dong, Chung-gu, Seoul 100770, South Korea; tel: +822 726 5555; fax: +822 778 2514; email: ychang@kaltour.com Website: http://www.afsmc2002.or.kr

\section{Australian College of Sports \\ Physicians (ACSP) 2002 \\ Conference in conjunction with the New Zealand Sports \\ Medicine Conference}

30 October-3 November 2002, Christchurch, New Zealand

Keynote speaker will be Assitant Professor Karim Khan from Vancouver, Canada. Call for abstracts will be announced in early 2002

Further details: Rob Campbell; email rcampbell@sportsmed-nz.co.nz

Website: www.acsp.com.au

\section{Second World Congress of} Science and Medicine in Cricket

4-7 February 2003, University of Port Elizabeth, South Africa

Further details: Dr Richard Stretch, University of Port Elizabeth, PO Box 1600, Port Elizabeth 6000, South Africa; tel: +27 41 5042584; fax: +27 41 5832605; email: sparas@upe.ac.za

\section{Vth World Congress on Science \& Football}

April 2003, Lisbon, Portugal

Further details: Dr J Cabri: Faculdade de Motricidade Humana, Estrada da Costa, Cruz Quebrada, 1499 Lisbon, Portugal; tel: +1 780 436 5529; fax: +1 780437 6710; email: Jcabri@fmh.utl.pt

Website: http://www.fmh.utl.pt/wesf

\section{NOTES AND NEWS}

\section{www.basem.co.uk}

The British Association of Sport and Exercise Medicine has launched its new websitewww.basem.co.uk. The site provides information about the educational opportunities in sport and exercise medicine and advice to those wishing to become involved in this area.

\section{Interested in Sports Medicine? Gain a higher degree from Australia's leading University}

The Centre for Sports Medicine Research and Education is a multidisciplinary Centre located in the Faculty of Medicine, Dentistry and Health Sciences at the University of Melbourne, Australia. It combines world-class researchers and clinicians working in the area of sports medicine.

\section{Research Higher Degrees}

The Centre offers Doctor of Philosophy (PhD), Master of Sports Medicine, Master of Physiotherapy, Master of Science, and Doctor of Medicine degrees. These are available to graduates of health and medical science courses such as physical therapy, medicine and human movement.

Educational programme

The Centre offers a one month full time Postgraduate Certificate in Sports Physiotherapy: spine, pelvis, and lower limb. Instructors are eading clinical experts and researchers in the multidisciplinary approach to sports medicine. The Certificate will run from Nov 4-29 in 2002.

Please contact: A/Professor Peter Brukner: p.brukner@unimelb.edu.au (Research Degrees ), A/Professor Kim Bennell: k.bennell $a$ unimelb.edu.au (Research Degrees), $\mathrm{Mr}$ Henry Wajswelner: h.wajswelner@unimelb. edu.au (Certificate Courses).

Website: www.physioth.unimelb.edu.au/csmre

\section{Sports medicine}

The University of New South Wales Masters of Sports Medicine

You don't have to leave your practice:

- Delivery by Distance Education

- Videos, CD-ROMS and online learning

- All aspects of Sports Medicine covered

- Locally organised examinations

- Clinical training

- Certificate and Diploma courses also offered

Further details: Sports Medicine Programs, UNSW Sydney 2052, Australia; tel: 612938 2557; fax: 6129313 8629; email: sportsmed@unsw.edu.au

Website: www.med.unsw.edu.au/sportsmed 


\section{Expression of concern about content of which Dr Paul McCrory is a single author}

This paper is authored by Dr Paul McCrory. During 2021 and 2022 there was an investigation by BJSM and BMJ which found that some of his work was the product of publication misconduct. Such misconduct includes plagiarism, duplicate publication, misquotation and misrepresentation in publications in respect of which he was listed as the sole author. ${ }^{1}$ We are placing a notice to readers on all content in relation to which he is identified as the sole author to alert them to the conclusions of our investigation.

(C) Author(s) (or their employer(s)) 2022. No commercial re-use. See rights and permissions. Published by BMJ.

Br J Sports Med 2022;0:1. doi:10.1136/bjsports-2022-106408eoc

D) Check for updates

\section{REFERENCE}

1 Macdonald H, Ragavooloo S, Abbasi K. Update into the investigation of former BJSM editor-in-chief Paul McCrory. Br I Sports Med 2022. 